\title{
CHLOROPOLYSPORINS A, B AND C, NOVEL GLYCOPEPTIDE ANTIBIOTICS FROM FAENIA INTERJECTA SP. NOV. ${ }^{\dagger}$
}

\section{TAXONOMY OF PRODUCING ORGANISM}

\author{
Takao Okazaki, Ryuzo Enokita, Hiroko Miyaoka, \\ Toshio Takatsu and Akio Torikata \\ Fermentation Research Laboratories, Sankyo Co., Ltd., \\ 1-2-58 Hiromachi, Shinagawa-ku, Tokyo 140, Japan
}

(Received for publication November 25, 1986)

\begin{abstract}
Strain SANK 60983, an actinomycete isolated from a soil sample, was found to produce the new glycopeptide antibiotics, chloropolysporins A, B and C. Short chains of spores occur in the both aerial and substrate hyphae. meso-Diaminopimelic acid is present in the cell wall and galactose and arabinose in the whole-cell hydrolysate. Mycolic acid is absent. On the basis of the morphological, cultural and physiological characteristics, this strain was determined to be a new species of Faenia designated Faenia interjecta sp. nov. The type strain of $F$. interjecta Okazaki and Enokita is SANK 60983.
\end{abstract}

In the course of an extensive screening program for new antibiotics produced by rare actinomycetes, new antibiotics, chloropolysporins, were discovered in our laboratories. This paper deals with the taxonomy of the producing organism. Fermentation, isolation, physico-chemical characterization and structure elucidation as well as biological properties of the antibiotics will be described in subsequent papers.

\section{Materials and Methods}

Actinomycete Strain

Strain SANK 60983 was isolated from a soil sample collected at Kuroiso, Tochigi Prefecture, Japan. One drop of the water suspension of the soil sample was plated on the surface of $\mathrm{NH}_{4} \mathrm{Cl}$-glycerol agar medium consisting of glycerol $1.5 \%, \mathrm{NH}_{4} \mathrm{Cl} 0.2 \%, \mathrm{CaCO}_{3} 0.1 \%, \mathrm{~K}_{2} \mathrm{HPO}_{4} 0.05 \%, \mathrm{MgSO}_{4} \cdot 7 \mathrm{H}_{2} \mathrm{O}$ $0.5 \%, \mathrm{FeSO}_{4} \cdot 7 \mathrm{H}_{2} \mathrm{O} 0.001 \%$ and agar $2.0 \%$ at $\mathrm{pH} 7.0$ before sterilization. The plate was incubated at $28^{\circ} \mathrm{C}$ for 10 days.

The strain SANK 60983 was inoculated into International Streptomyces Project (ISP) medium 1 in a Sakaguchi flask and grown for 3 days at $28^{\circ} \mathrm{C}$ on a reciprocal shaker. After harvesting by centrifugation, the culture was washed twice with sterile distilled water by centrifugation, and then used as inoculum for various studies. In addition to the ISP media described by SHIRLING and GotTLIEB ${ }^{1)}$, several agar media recommended by WAKSMAN ${ }^{2)}$ were also used in this study.

Morphological Characterization

The spore chain morphology and the hyphae of the strain grown on various agar media at $28^{\circ} \mathrm{C}$ for $14 \sim 21$ days were determined with a light microscope. A sample, treated with a critical point dryer (HCP-1, Hitachi Co., Ltd.) after stepwise dehydration by ethanol, was observed under an MSM-6 scanning electron microscope (Akashi Seisakusho Co., Ltd.).

Cultural Characterization

Observation of the growth on various agar media was made after incubation at $28^{\circ} \mathrm{C}$ for 14 days unless otherwise mentioned. The mass colors of the growth were assigned in common terminology.

\footnotetext{
$\uparrow$ Micropolyspora interjecta SANK 60983 (FERM BP-538).
} 
Exact colors were determined by comparing the mycelial color with color chips from the "Guide to Color Standard" (Nippon Shikisai Kenkyusho, Tokyo, Japan).

\section{Physiological Tests}

Physiological tests were carried out with each medium as follows: ISP media 1, 6 and 7 for melanin formation, ISP medium 4 for starch hydrolysis, gelatin stab for gelatin liquefaction, dehydrated skim milk (Difco) for milk coagulation and peptonization, nitrate broth (Difco) for nitrate reduction. The media used for determination of casein, tyrosine and xanthine decomposition were prepared by dissolving $10 \mathrm{~g}$ of dehydrated skim milk in $100 \mathrm{ml}$ of distilled water and by dissolving $0.5 \mathrm{~g}$ of tyrosine or $0.4 \mathrm{~g}$ of xanthine in $100 \mathrm{ml}$ of nutrient agar, respectively. The cultures on all of the media tested were incubated at $28^{\circ} \mathrm{C}$ for 14 days except on milk $\left(37^{\circ} \mathrm{C}, 10\right.$ days $)$ and gelatin $\left(26^{\circ} \mathrm{C}, 21\right.$ days $)$ media. Carbohydrate utilization was studied by the procedure described by SHIRLING and GotTLIEB. The effect of temperature on growth was determined by streaking the inoculum over the surface of ISP medium 2 with a temperature gradient incubator TN-3 (Toyo Kagaku Sangyo Co., Ltd.). The tolerance against sodium chloride of the culture was investigated by streaking the inoculum onto the same medium as used for the temperature study, except that it contained sodium chloride at 1.0, 2.0,3.0,5.0,7.0,10.0 or $14.0 \%$ and incubating at $28^{\circ} \mathrm{C}$ for 21 days. The susceptibility of the strain to antibiotics was determined by the agar dilution method (ISP medium 2) at $\mathrm{pH}$ 7.0. Growth under anaerobic condition was performed by the Gas Pak system (BBL) using the same method and medium as those for the sodium chloride tolerance and temperature studies.

\section{Chemotaxonomy}

Purified cell wall and whole-cell hydrolysates were analyzed by the methods of BeCKER et al. ${ }^{3)}$, LeCHEVAlier and LeChevalieR ${ }^{4}$. Phospholipid, acyl type in cell wall, menaquinones and mycolic acid were performed by the methods of LeChevalier and LeCHEvalier ${ }^{5}$, UCHIDA and AIDA ${ }^{6)}$, ColiINS et al. $^{7\rangle}$ and HeCHT and CAUSEY ${ }^{8)}$, respectively.

\section{Results and Discussion}

\section{Morphological Characterization}

Strain SANK 60983 grows relatively well on various media. The aerial mycelium is hardly visible on most media but may occasionally be visible on glycerol - asparagine agar or on potato extract - carrot extract agar. The aerial mycelium arises from the substrate mycelium. The aerial hyphae are $0.6 \sim$ $1.2 \mu \mathrm{m}$ in diameter and vegetative hyphae are $0.5 \sim 0.8 \mu \mathrm{m}$ in diameter. Both the aerial and the vegeta-

Plate 1. Photomicrograph of strain SANK 60983 (on potato extract - carrot extract agar, $28^{\circ} \mathrm{C}, 21$ days $\times 300$ ).

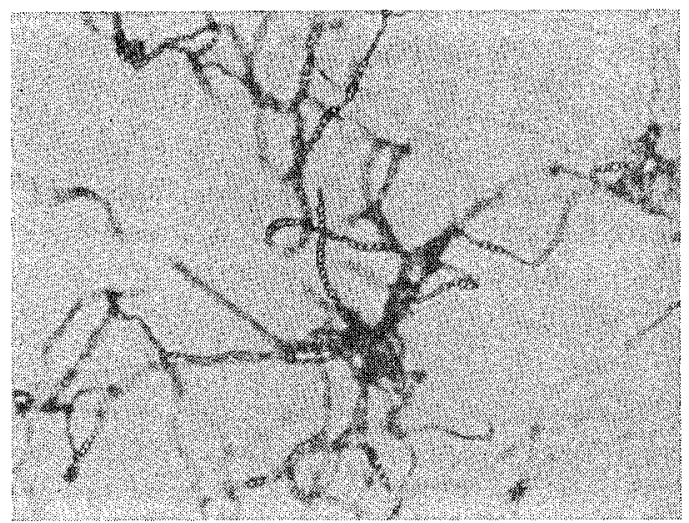

Plate 2. Scanning electron micrograph of spores of strain SANK 60983 (on potato extract - carrot extract agar, $28^{\circ} \mathrm{C}, 14$ days).

Bar represents $1 \mu \mathrm{m}$.

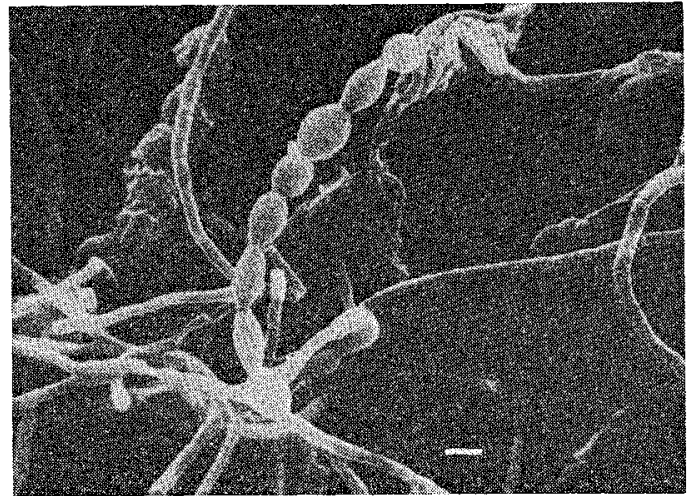


tive hyphae bear short chains of intercalary and terminal spores, normally from 1 to 10 , although occasionally there are more than 10 spores (Plate 1).

The spores were spherical to oval with a smooth surface and $0.4 \sim 1.5$ by $0.5 \sim 1.2 \mu \mathrm{m}$ in size as revealed by scanning electron microscopy and shown in Plates 2 and 3. No distinctive fragmentation of the hyphae was observed although it may be seen during later stages of the culture. Development of whirls, sporangia, or other special organs was not observed on the media employed.
Plate 3. Scanning electron micrograph of spores of strain SANK 60983 (on potato extract - carrot extract agar, $28^{\circ} \mathrm{C}, 14$ days). Bar represents $1 \mu \mathrm{m}$.

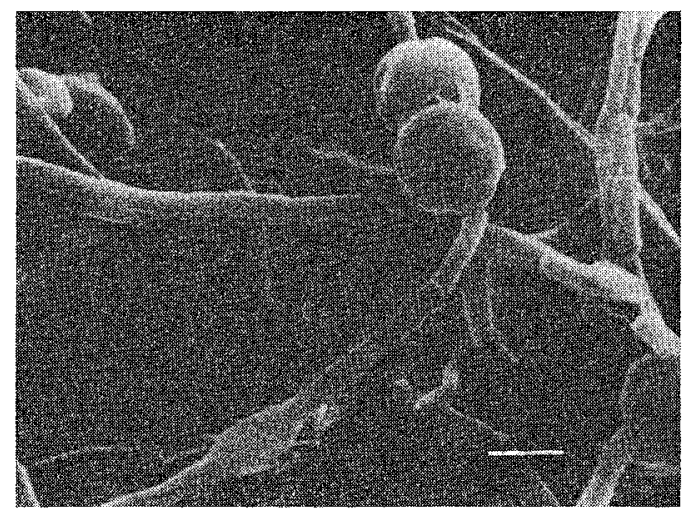

\section{Cultural Characteristics}

The vegetative growth colors of strain SANK 60983 are pale yellow, yellowish brown or yellowish gray. Aerial hyphae are not produced on most media, although white aerial hyphae are produced on some media. No soluble pigment is produced. Table 1 shows the results obtained after cultivation for 14 days at $28^{\circ} \mathrm{C}$ on various culture media.

\section{Physiological Properties}

The physiological properties of strain SANK 60983 are shown in Table 2. Although coagulation and peptonization of skim milk are both shown as negative, they may occasionally turn positive after long-term incubation. The organism did not grown under anaerobic conditions. It was able to survive after incubation at $50^{\circ} \mathrm{C}$ for 8 hours. The temperature range for growth was $20 \sim 37^{\circ} \mathrm{C}$. Growth in 5 to $7 \% \mathrm{NaCl}$ was inconsistent. No growth occurred at $10 \%$. The strain was resistant to $100 \mu \mathrm{g} / \mathrm{ml}$ of tetracycline, kanamycin, carbenicillin, novobiocin, nystatin, cycloheximide and amphotericin B. Minimal inhibitory concentrations $(\mu \mathrm{g} / \mathrm{ml})$ of streptomycin, ampicillin, chloramphenicol, gentamicin, cephaloridine, erythromycin, benzylpenicillin and rifamycin were $1.5,6.25,12.5,12.5,12.5,25.0,50.0$ and 50.0 , respectively.

\section{Chemotaxonomy}

meso-Diaminopimelic acid, arabinose and galactose were found to be present in the cell walls, which are thus of Type IV, and the whole cell sugar pattern was Type A. The types of acyl group of the cell wall and major menaquinone were acetyl type and MK-9 $\left(\mathrm{H}_{4}\right)$. Phospholipid type was probably PIII, as a small amount of phosphatidylcholine was detected. Mycolic acid was not detected.

\section{Identification and Classification}

A comparison of the description of strain SANK 60983 with the actinomycetes listed in the Approved lists of bacterial names ${ }^{9)}$, BERGEY's Manual of Systematic Bacteriology ${ }^{10)}$ and recent taxonomic literature indicate that this organism is morphologically and chemotaxonomically related to the micropolysporas group; Actinopolyspora, Saccharopolyspora, Pseudonocardia and Faenia (Table 3).

However, the genera Actinopolyspora and Saccharopolyspora have spores growing only on the tips of aerial hyphae; the former is as highly halophilic genus, while the acyl type of the cell wall of the 
Table 1. Cultural characteristics of strain SANK 60983.

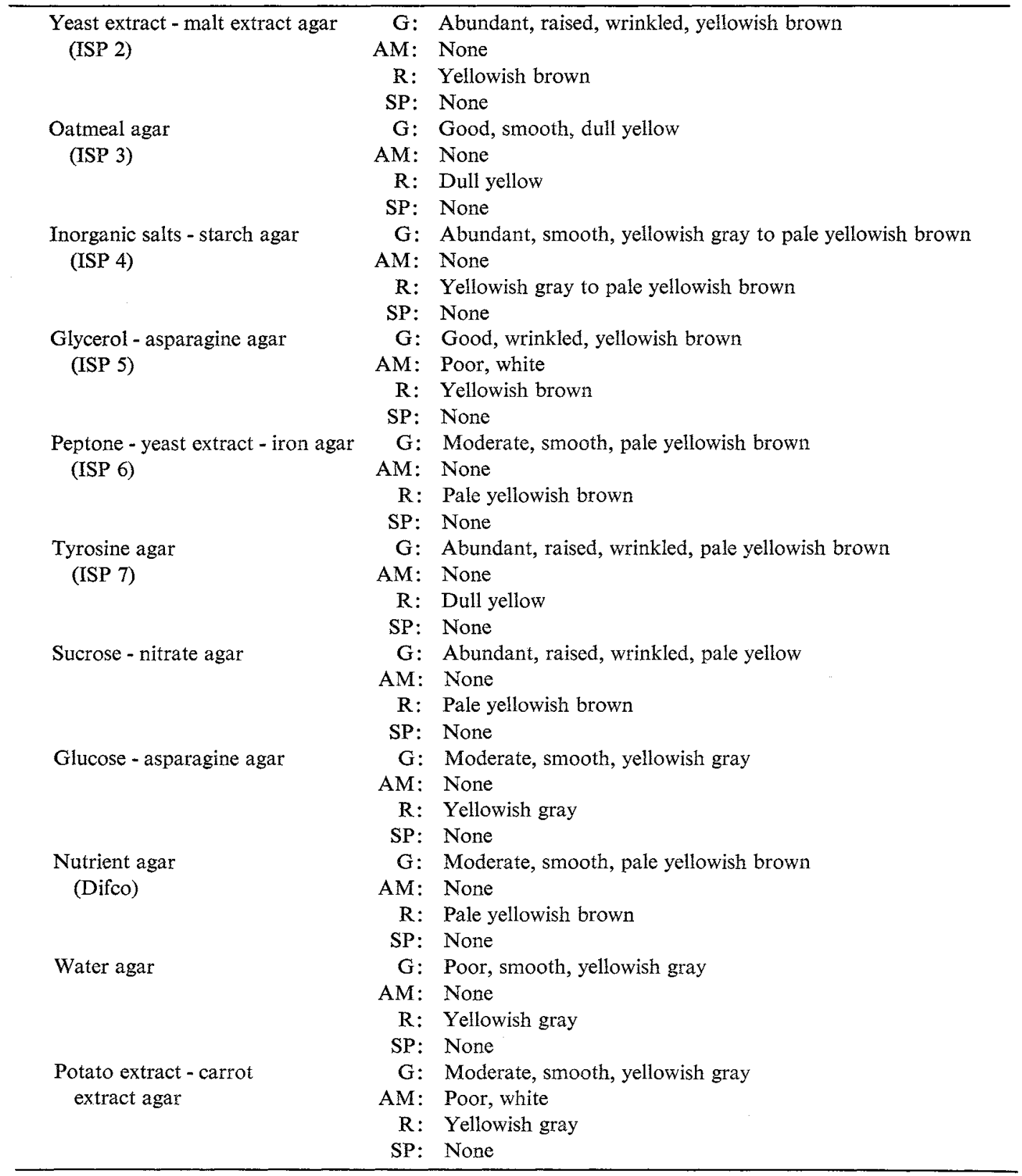

G: Growth, AM: aerial mycelium, R: reverse color, SP: soluble pigment.

latter is the glycolyl type. For these reasons, strain SANK 60983 can not be assigned to either of these genera. Although the genus Pseudonocardia bears spores both on aerial and substrate mycelia, as does strain SANK 60983, it forms acropetally long and cylindrical spores. Thus, strain SANK 60983 can

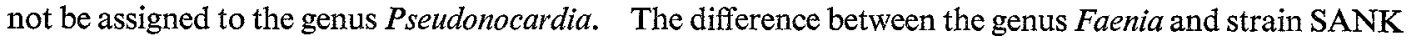
60983 is the growth temperature. The former grows on most complex media at 35 to $60^{\circ} \mathrm{C}$, while the latter at 20 to $42^{\circ} \mathrm{C}$, although it is thermoduric. However, it seems correct to regard strain SANK 60983 as a member of the genus Faenia. 
Table 2. Physiological properties of strain SANK 60983.

\begin{tabular}{|c|c|c|c|c|c|}
\hline \multirow{5}{*}{ Decomposition: } & Adenine & - & & D-Mannitol & + \\
\hline & Casein & + & & D-Fructose & + \\
\hline & Xanthine & - & & L-Rhamnose & + \\
\hline & Hypoxanthine & + & & Sucrose & + \\
\hline & Urea & + & & Raffinose & \pm \\
\hline \multicolumn{2}{|c|}{ Starch hydrolysis } & \pm & Utilization of & D-Glucose & + \\
\hline \multicolumn{2}{|c|}{ Gelatin liquefaction } & + & carbon sources: & L-Arabinose & + \\
\hline \multicolumn{2}{|c|}{ Milk coagulation } & - & & D-Xylose & + \\
\hline \multicolumn{2}{|l|}{ Milk peptonization } & - & & Inositol & + \\
\hline \multicolumn{2}{|l|}{ Nitrate reduction } & + & & D-Mannitol & + \\
\hline \multicolumn{2}{|c|}{ Deoxyribonuclease secretion } & + & & D-Fructose & + \\
\hline \multirow[t]{3}{*}{ Melanin formatior } & on: ISP 1 & - & & L-Rhamnose & + \\
\hline & ISP 6 & - & & Sucrose & + \\
\hline & ISP 7 & - & & Raffinose & \pm \\
\hline \multicolumn{3}{|c|}{ Acid production from: } & Growth in $\mathrm{NaCl}$ : & $3 \% \mathrm{w} / \mathrm{v}$ & + \\
\hline & Sodium acetate & - & & $5 \% \mathrm{w} / \mathrm{v}$ & \pm \\
\hline & Sodium succinate & - & & $7 \% \mathrm{w} / \mathrm{v}$ & \pm \\
\hline & Sodium citrate & - & & $10 \% \mathrm{w} / \mathrm{v}$ & - \\
\hline & Sodium pyruvate & - & Range of growth & $10^{\circ} \mathrm{C}$ & - \\
\hline & Sodium tartrate & - & & $20^{\circ} \mathrm{C}$ & + \\
\hline & D-Glucose & + & & $28^{\circ} \mathrm{C}$ & + \\
\hline & x-Arabinose & + & & $37^{\circ} \mathrm{C}$ & + \\
\hline & D-Xylose & + & & $42^{\circ} \mathrm{C}$ & \pm \\
\hline & Inositol & + & & $45^{\circ} \mathrm{C}$ & - \\
\hline
\end{tabular}

$+:$ Positive, - : negative, \pm : slightly positive.

Table 3. Comparison of strain SANK 60983 with known micropolysporas.

\begin{tabular}{|c|c|c|c|c|c|}
\hline & $\begin{array}{c}\text { Actino- } \\
\text { polyspora }\end{array}$ & $\begin{array}{l}\text { Saccharo- } \\
\text { polyspora }\end{array}$ & $\begin{array}{l}\text { Pseudo- } \\
\text { nocardia }\end{array}$ & Faenia & $\begin{array}{l}\text { SANK } \\
60983\end{array}$ \\
\hline Aerial mycelium & + & + & + & + & + \\
\hline Fragmentation of $\mathrm{SM}^{*}$ & + & + & + & \pm & \pm \\
\hline Sporophores & $\mathrm{AM}(\mathrm{T})^{*}$ & $\mathrm{AM}(\mathrm{T})$ & $\operatorname{AMSM}(\mathrm{T})$ & $\operatorname{AMSM}(I T)$ & $\operatorname{AMSM}(\mathrm{IT})$ \\
\hline Motility & - & - & - & - & - \\
\hline Cell wall type & IV & IV & IV & IV & IV \\
\hline Whole cell sugar pattern & A & A & $\mathrm{A}$ & $\mathrm{A}$ & A \\
\hline Mycolic acid & NT & - & - & - & - \\
\hline Acyl type & $\mathrm{Ac}$ & Gly & Ac & Ac & Ac \\
\hline Menaquinone (MK) & MK-9 & MK-9 & MK-8/9 & MK-9 & MK-9 \\
\hline
\end{tabular}

* SM: Substrate mycelium, AM: aerial mycelium, T: tip of hyphae, I: intercalary.

NT: Not tested.

Faenia rectivirgula, the type species of the genus Faenia is the only species of the genus and the strain grows at 33 to $60^{\circ} \mathrm{C}$ with the best growth occurring between 50 and $55^{\circ} \mathrm{C}$.

Although the genus Faenia has thermophilic character, it seems to be reasonable to give the genus Faenia for actinomycetes having spore chains both on the substrate and on the aerial mycelia, and with type IV cell wall. Therefore, we propose, tentatively, strain SANK 60983 as a new species of the genus Faenia and designate it as $F$. interjecta Okazaki and Enokita sp. nov. Etymology; derived from L. interjectus, referring to spores in the middle of the hyphae. The strain of $F$. interjecta has been deposited in the Fermentation Research Institute, Agency of Industrial Science and Technology, Ibaraki Prefecture, Japan, with the accession number of FERM BP-538. 


\section{Discussion}

Strain SANK 60983 was originally proposed as a new species of the genus Micropolyspora which includes the following five species; Micropolyspora brevicatena, Micropolyspora internatus, Micropolyspora angiospora, Micropolyspora rectivirgula and Micropolyspora faeni (Approved lists of bacterial names, $1980^{\circ)}$ ). However, M. brevicatena has been transferred to the genus Nocardia ${ }^{11}$ because it possesses mycolic acid in its cell wall. M. internatus and $M$. angiospora can not also be accommodated in the genus Micropolyspora. Because the former has mostly single spores similar to the genus Saccharomonospora and the latter shows the cell wall type III similar to the genus Actinomadura or Excellospora. Besides, there is little doubt that $M$. rectivirgula and $M$. faeni are synonymous despite considerable differences between the original descriptions of these two species.

Under such confusing status of the genus Micropolyspora, KURUP and AGRE ${ }^{12}$ proposed the name Faenia gen. nov. for the genus Micropolyspora. Because, M. brevicatena, the type species of the genus Micropolyspora has been transferred from Micropolyspora to the genus Nocardia, whereas McCARTHY et $a{ }^{13)}$ and LACEY et al. ${ }^{14)}$ proposed to conserve the genus name Micropolyspora with $M$. faeni Cross, Maciver, and Lacey as the type species.

The Judicidal Commission recently announced that the genus Faenia, with type species Faenia rectivirgula, as validly published by Kurup and Agre remains legitimate ${ }^{15}$. Accordingly, we decided to designate strain SANK 60983 as Faenia interjecta.

\section{References}

1) Shirling, E. B. \& D. Gotrlieb: Methods for characterization of Streptomyces species. Int. J. Syst. Bacteriol. 16: 313 340, 1966

2) Waksman, S. A. $(E d$.$) : The Actinomycetes. Classification, Identification and Description of Genera and$ Species. Vol. 2. Williams \& Wilkins Co., Baltimore, 1961

3) BeCKer, B.; M. P. LeCheVAlier \& H. A. LeChevalier: Chemical composition of cell-wall preparation from strains various form-genera of aerobic actinomycetes. Appl. Microbiol. 13: 236 243, 1965

4) Lechevalier, M. P. \& H. A. Lechevaluer: Chemical composition as a criterion in the classification of aerobic actinomycetes. Int. J. Syst. Bacteriol. 20: 435 443, 1970

5) Lechevalier, M. P. \& H. A. Lechevalier: The chemotaxonomy of actinomycetes. In A Actinomycete Taxonomy. SIM Special Publication No. 6. Eds., A. DIETZ \& D. W. ThaYER, pp. 227 291, Society for Industrial Microbiology, Arlington, 1980

6) UCHIDA, K.\& K. AIDA: Acyl type of bacterial cell wall: Its simple identification by colorimetric method. J. Gen. Appl. Microbiol. 23: 249 260, 1977

7) Collins, M. D.; T. Pirous \& M. Goodfellow: Distribution of menaquinones in actinomycetes and corynebacteria. J. Gen. Microbiol. 100: 221 230, 1977

8) HeChT, S. T. \& W. A. CAUseY: Rapid method for the detection and identification of mycolic acids in aerobic actinomycetes and related bacteria. J. Clin. Microbiol. 4: 284 287, 1976

9) Skerman, V. B. D.; V. McGowan \& P. H. A. SNEAth: Approved lists of bacterial names. Int. J. Syst. Bacteriol. 30: 225 420, 1980

10) SNeAth, P. H. A. (Ed.): Bergey's Manual of Systematic Bacteriology. Vol. 2. Williams \& Wilkins Co., Baltimore, 1986

11) Goodfellow, M. \& T. Pirouz: Numerical classification of sporoactinomycetes containing meso-diaminopimelic acid in the cell wall. J. Gen. Microbiol. 128: 503 527, 1982

12) KURUP, V.P. \& H.S. AGre: Transfer of Micropolyspora rectivirgula (Krassilnikov and Agre 1964) Lechevalier, Lechevalier, and Becker 1966 to Faenia gen. nov. Int. J. Syst. Bacteriol. 33: 663 665, 1983

13) McCarthy, A. J.; T. Cross, J. Lacey \& M. Goodfellow: Conservation of the name Micropolyspora Lechevalier, Solotorovsky, and McDurmont and Designation of Micropolyspora faeni Cross, Maciver, and Lacey as the type species of the genus. Int. J. Syst. Bacteriol. 33: 430 433, 1983

14) LACEY, J.; A. J. MCCARTHY, M. Goodfellow \& T. Cross: Conservation of the name Micropolyspora 
Lechevalier, Solotorovsky, and McDurmont over Faenia Kurup and Agre and designation of Micropolyspora faeni Cross, Maciver, and Lacey as the type species of the genus amended request for an opinion. Int. J. Syst. Bacteriol. 34: 505 507, 1984

15) WAYNe, L. G.: Actions of the judicidal commission of the international committee on systematic bacteriology on request for opinions published in 1983 and 1984. Int. J. Syst. Bacteriol. 36: 357 358, 1986 